\title{
Sistem Keamanan Sepeda Motor Menggunakan Kata sandi Berbasis Arduino Nano
}

\author{
Dwiyana Indra Prasetya ${ }^{1}$, Mushlihudin ${ }^{2}$ \\ ${ }^{1}$ Program Studi Teknik Elektro, ${ }^{2}$ Program Studi Teknik Informatika, \\ ${ }_{1,2}$ Fakultas Teknologi Industri, Universitas Ahmad Dahlan \\ Kampus 3, Jln. Prof.Dr. Supomo, Janturan, Yogyakarta 55164 \\ e-mail: dwiyanaindraprasetya@ee.uad.ac.id ${ }^{1}$, mushlihudin@tif.uad.ac.id ${ }^{2}$
}

\begin{abstract}
In this moment, amount of the motorcycle vehicle is fast increasing. Everyone have a motorcycle also more than it. Over use of the motorcycle impact are stealing improved every year. This research has conducted a security system for motorcycles based on Arduino Nano which is to protect it. Our method is used a password to control the machine power. This system is calculating a mistake the password entried in three times frequency and also it can trigger the alarm sound, so the machine cannot be activated. This system is mounted with the infrared remote which used to control the alarm sound on specific range. As for user is entrying the password correct and the Arduino Nano connected with relay coil then the machine work. Result of this research is shown accuracy of $100 \%$ when the password correct or wrong are trained. In Addition, the remote has proven work the alarm sound activating with accuracy of $100 \%$ in one meter, $80 \%$ in three meters, and $60 \%$ in seven meters.
\end{abstract}

Keywords: Security system of motorcycle; Arduino nano; Security password ; Motorcycle; Infrared remote.

\begin{abstract}
Abstrak
Pada saat ini, jumlah kendaraan bermotor semakin meningkat. Hampir setiap orang mempunyai sebuah sepeda motor bahkan lebih. Banyaknya sepeda motor tersebut berdampak pada tindakan pencurian sepeda motor yang semakin meningkat dari tahun ke tahun. Penelitian ini akan merancang sebuah sistem pengaman sepeda motor berbasis Arduino Nano untuk mencegah pencurian sepeda motor. Metode yang digunakan pada sistem pengaman sepeda motor ini dengan cara memasukkan kata sandi untuk menyalakan mesin. Sistem ini menghitung kesalahan masukan kata sandi sebanyak tiga kali yang akan memicu alarm berbunyi dan mesin motor tidak dapat dinyalakan. Sistem ini juga dilengkapi dengan Infrared remote yang berguna untuk mematikan alarm yang berbunyi dari jarak tertentu. Pada saat kata sandi yang dimasukkan benar maka Arduino Nano akan menghubungkan relay coil sehingga mesin motor dapat dinyalakan. Berdasarkan pengujian sistem pengaman sepeda motor ini diperoleh hasil bahwa saat memasukkan kata sandi benar dan salah persentase keberhasilannya sebanyak $100 \%$. Sedangkan pada saat mematikan alarm menggunakan kendali jarak jauh dengan jarak 1 meter, 3 meter, dan 7 meter akurasi keberhasilannya $100 \%$, 80\%, dan $60 \%$.
\end{abstract}

Kata kunci : Keamanan sepeda motor; Arduino nano; Kata sandi keamanan; Sepeda motor; Infrared remote.

\section{Pendahuluan}

Kepemilikan sepeda motor semakin meningkat dari tahun ke tahun. Hal ini terbukti dengan meningkatnya penjualan sepeda motor. Berdasarkan data yang dikeluarkan oleh Direktorat Lalu Lintas Polda Metro Jaya pada tahun 2014, jumlah kendaraan bermotor di Jakarta dan sekitarnya bertambah sebanyak 5.500 hingga 6.000 unit kendaraan per hari [1]. Jumlah tersebut didominasi oleh pertambahan sepeda motor yang mencapai 4.000 hingga 4.500 per hari, Sedangkan 
kendaraan roda empat mengalami pertumbuhan sebanyak 1.600 unit per hari. Meningkatnya pemilik kendaraan sepeda motor berdampak pada semakin banyaknya tindakan pencurian sepeda motor. Berikut ini adalah data statistik pencurian sepeda motor yang diperoleh dari Badan Pusat Statistika Indonesia (BPS) 2014. Pada tahun 2011 sebanyak 35.688 kasus, tahun 2012 39.217 kasus dan pada tahun 2013 ada 41.816 kasus pencurian sepeda motor [2]. Berbagai modus dilakukan untuk mengelabuhi si pemilik kendaraan. Sebagai pemilik kendaraan, kita dituntut menjamin kendaraan aman dari pencurian. Pencurian sepeda motor dilakukan dengan banyak cara oleh para oknum. Salah satunya dengan menggunakan perangkat kunci jenis letter "T" [3]. Alat ini dinamakan kunci letter "T" karena bentuknya menyerupai huruf "T". Adapaun cara lain yang digunakan pelaku pencurian adalah berupa campuran bahan kimiawi berasal dari unsur $\mathrm{HCl}$ (asam klorida) dan $\mathrm{HNO} 3$ (asam nitrat) [4]. Cairan ini dapat membuat jenis baja, besi atau alumunium pada kunci motor menjadi korosi yang menyebabkan dalam waktu singkat akan terkikis dan mudah dibobol secara paksa. Desain sistem keamanan kendaraan bermotor oleh pabrikan hingga saat ini masih memiliki kelemahan sehingga memudahkan terjadinya kejadian pencurian motor jika pemilik lengah dalam menjaga kendaraanya. Maka dari itu diperlukan sebuah sistem pengaman untuk mencegah tindakan pencurian sepeda motor.

Ada beberapa penelitian yang telah merancang desain sistem keamanan lebih kompleks melalui penggunaan kata sandi dan alarm, sistem tersebut terpasang tombol angka, relai dan buzzer sebagai media aktivasi sistem [5-8]. Adapaun rancang desain sistem keamanan menggunakan Infrared remote [9]. Penelitian ini melakukan rancang bangun desain sistem keamanan kendaraan bermotor dengan menerapkan fungsi-fungsi tersebut dengan mengaplikasikan kendali CDI (Capacitor Discharge Ignition) dan dikendalikan secara automatis menggunakan modul Arduino Uno [10-12].

\section{Metode Penelitian}

Perancangan sistem dilakukan dalam dua tahap perancangan yaitu perancangan perangkat keras dan perancangan perangkat lunak. Bahan yang digunakan ditunjukkan pada Gambar 1.

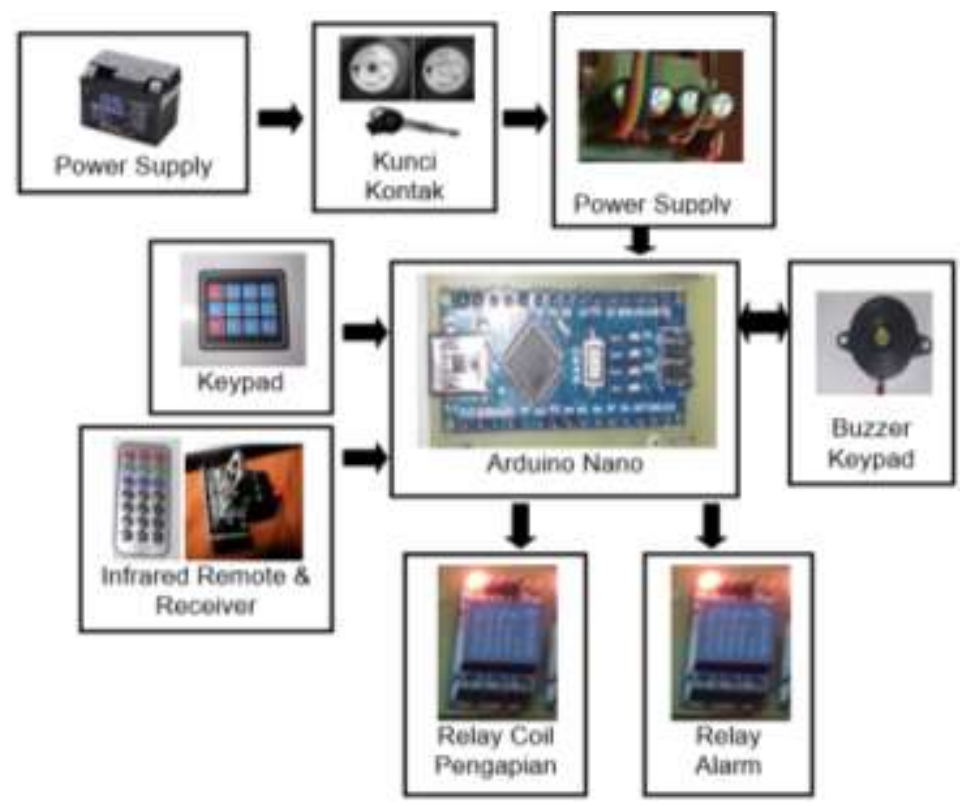

Gambar 1. Diagram blok alur kerja rangkaian komponen sistem keamanan sepeda motor.

Pada Gambar 1 menunjukkan beberapa komponen elektronis yang digunakan. Proses kerja komponen elektronis tersebut yakni ketika kunci sepeda motor dinyalakan maka regulator tegangan bekerja sebagai pengendali daya. Regulator tegangan mengubah tegangan 12 volt menjadi 5 volt yang digunakan untuk mensuplai tegangan pada Arduino Nano. Keypad 3x4 berguna untuk memasukkan kata sandi dan saat tombol angka ditekan maka buzzer akan berbunyi. Pada saat kata sandi yang dimasukkan benar, maka relay coil pengapian aktif dan saat 
memasukan kata sandi salah sebanyak tiga kali maka relay alarm aktif dan relay coil tetap dalam kondisi mati. Infrared remote berfungsi mematikan alarm sepeda motor.

Dari diagram blok alur kerja rangkaian komponen sistem keamanan sepeda motor pada Gambar 1 dapat dibuat rangkaian alat yang ditunjukkan pada Gambar 2.

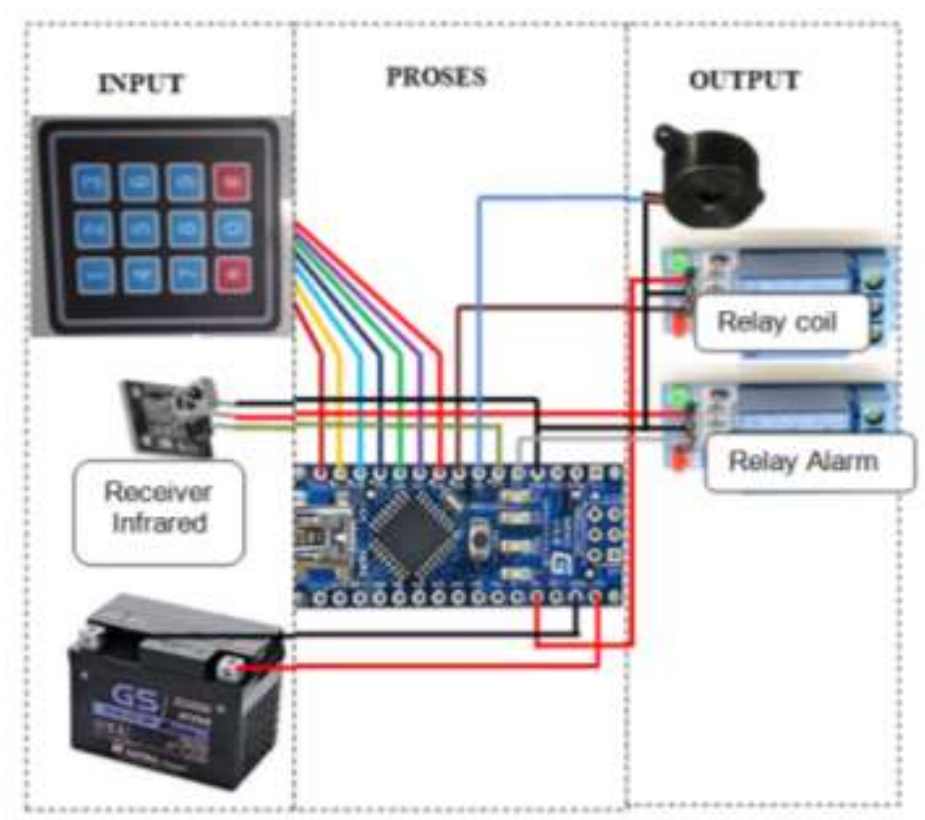

Gambar 2. Rangkaian perangkat komponen elektronis

Rancangan sistem pengaman sepeda motor ini menggunakan 2 buah relay sebagai penghantar coil dan alarm. Relay coil berfungsi sebagai pemutus dan penghubung tegangan dari CDI menuju coil. Relay coil ini dikendalikan oleh arduino nano melalui port keluaran D5. Sedangkan relay alarm berfungsi sebagai pemutus dan penghubung aliran listrik dari accu menuju alarm sirine. Relay alarm ini dikendalikan oleh arduino nano melalui port keluaran D2. Pada gambar tersebut terdapat keypad 3x4 yang digunakan untuk memberi masukkan kata sandi, serta receiver infrared sebagai penerima sinyal infrared untuk mematikan alarm. Gambar 2 merupakan rangkaian pengkabelan komponen alat dengan pin Arduino Nano untuk sistem pengaman sepeda motor menggunakan kata sandi berbasis Arduino Nano.

Pembuatan program sistem pengaman sepeda motor ini menggunakan software Arduino $I D E$. Sebelum menulis program melalui software Arduino IDE langkah pertama membuat diagram alir sistem (flowchart) sebagai acuan untuk penulisan program sehingga sistem yang dibuat dapat bekerja sesuai rencana. Adapun diagram alir sistem pengaman sepeda motor disajikan pada Gambar 3.

Jika semua proses perancangan prangkat telah selesai, langkah selanjutnya adalah pengujian sistem yang berguna untuk melihat sejauh mana sistem dapat bekerja sesuai fungsi dan tugasnya. Pengujian sistem meliputi pengujian perangkat keras dan pengujian keseluruhan sistem. Pengujian perangkat keras yaitu pengujian rangkaian regulator tegangan dan memastikan bahwa Arduino Nano pada saat kondisi kunci kontak sepeda motor dinyalakan Arduino Nano dalam kondisi menyala.

Pada pengujian keseluruhan sistem dilakukan dengan cara menghubungkan keseluruhan alat komponen dalam satu kesatuan rangkaian alat sistem pengaman sepeda motor menggunakan kata sandi berbasis Arduino Nano. Pengujian dilakukan bertujuan untuk memastikan bahwa sistem dapat bekerja dengan baik dan bagaimana mestinya sesuai dengan perintah yang sudah dimasukkan. 
Jurnal IImu Teknik Elektro Komputer dan Informatika (JITEKI)

Vol. 4, No. 1, Juni 2018

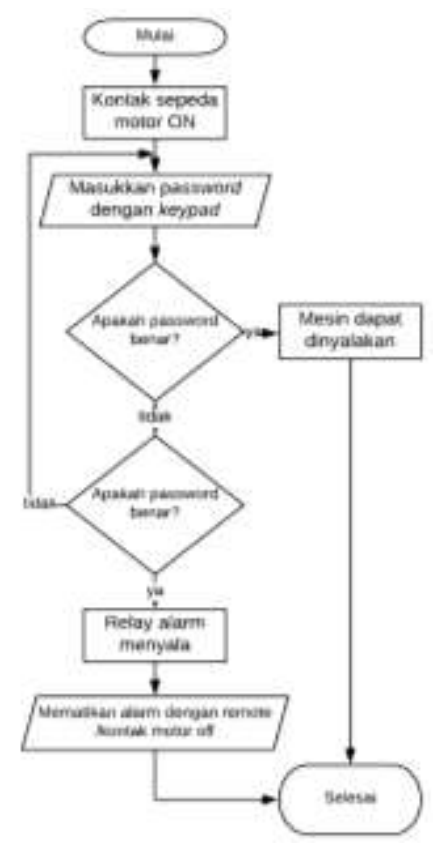

Gambar 3. Diagram alir sistem pengaman sepeda motor berbasis arduino nano

\section{Hasil Dan Pembahasan}

Pengujian pada penelitian ini dilakukan dengan dua tahap yaitu tahap pengujian sistem hardware dan pengujian keseluruhan sistem.

\subsection{Tahap pengujian rangkaian sistem}

Pengujian rangkaian sistem dilakukan untuk mengetahui seberapa akurat tegangan keluaran yang dihasilkan dari power supply sehingga tidak terjadi tegangan lebih yang dapat merusak arduino nano. Pengujian rangkaian sistem yaitu memastikan arduino nano dalam kondisi menyala. Pengujian yang dilakukan pada power supply yaitu dengan mengukur tegangan keluaran dari power supply dengan menggunakan multimeter. Pengamatan yang dilakukan tersebut didapat hasil berupa keluaran tegangan yang tidak jauh berbeda dengan tegangan yang diinginkan yaitu 5 volt. Pada pengujian ini mengamati tegangan keluaran dari IC regulator L7805. Pengujian selanjutnya dilakukan terhadap kondisi arduino nano yang bertujuan untuk memastikan bahwa pada saat kunci kontak sepeda motor dinyalakan arduino nano dalam kondisi ON. Indikator lampu led pada arduino menandakan bahwa arduino siap digunakan dan siap memproses program yang telah diupload. Hasil dari pengujian kondisi arduino dapat ditunjukkan pada Gambar 4.

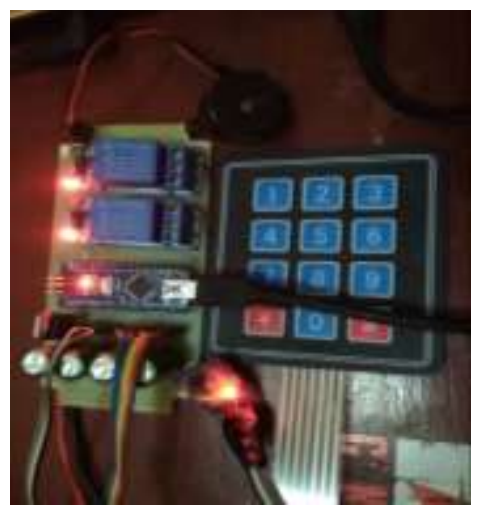

Gambar 4. Pengujian kondisi arduino 
Jurnal IImu Teknik Elektro Komputer dan Informatika (JITEKI)

Vol. 4, No. 1, Juni 2018

\subsection{Tahap pengujian keseluruhan sistem}

Pengujian keseluruhan sistem merupakan pengujian tahap terakhir. Pengujian ini dilakukan dengan cara menghubungkan keseluruhan sistem dalam satu rangkaian sistem pengaman sepeda motor menggunakan kata sandi berbasis arduino nano. Langkah pengujiannya adalah sebagai berikut:

1. Memastikan semua jalur dan alat telah terpasang dengan benar.

2. Memastikan saat kunci kontak sepeda motor ON maka kedua relay dan receiver infrared dalam kondisi siap digunakan.

3. Memastikan pada saat memasukan kata sandi benar maka relay coil ON.

4. Memastikan pada saat memasukan kata sandi 3 kali salah dengan kata sandi yang telah ditentukan maka alarm berbunyi.

5. Pengujian mematikan alarm dengan menggunakan infrared remote ketika memasukkan kata sandi salah tiga kali, juga menghitung jarak jangkau infrared remote.

Setelah memastikan semua jalur dan alat terpasang dengan baik, semua alat siap digunakan maka pengujian selanjutnya yaitu memasukkan kata sandi secara benar dengan memasukkannya pada keypad $3 \times 4$.

Untuk pengujian pada saat memasukan kata sandi terdapat beberapa parameter pengujian seperti pengujian saat memasukan kata sandi benar, pengujian saat memasukan kata sandi salah, dan pengujian jarak jangkauan infrared remote. Hasil dari pengujian adalah sebagai berikut

1. Pengujian saat memasukan kata sandi benar

Ketika kata sandi yang dimasukkan sesuai, maka relay coil yang dihubungkan dengan sambungan pada coil akan terhubung dan mesin dapat dinyalakan. Hasil pengujian saat memasukan kata sandi benar dapat ditunjukkan pada Tabel 1.

Tabel1. Hasil pengujian saat memasukan kata sandi benar.

\begin{tabular}{cccc}
\hline No & Percobaan & Kondisi Relay Coil & Kondisi mesin \\
\hline 1 & Percobaan 1 & Menyala & Menyala \\
2 & Percobaan 2 & Menyala & Menyala \\
3 & Percobaan 3 & Menyala & Menyala \\
4 & Percobaan 4 & Menyala & Menyala \\
5 & Percobaan 5 & Menyala & Menyala \\
6 & Percobaan 6 & Menyala & Menyala \\
7 & Percobaan 7 & Menyala & Menyala \\
8 & Percobaan 8 & Menyala & Menyala \\
9 & Percobaan 9 & Menyala & Menyala \\
10 & Percobaan 10 & Menyala & Menyala \\
\hline
\end{tabular}

Dari hasil pengujian pada Tabel 1 akurasi hasil optimum kondisi relay coil dan mesin dapat dihitung dengan persamaan sebagai berikut:

Akurasi kondisi relay coil $=\frac{\text { Total kondisi } \text { relaycoil menyala }}{\text { Total pengujian }} \times 100 \%$

$$
=\frac{10}{10} \times 100 \%=100 \%
$$

Akurasi kondisi mesin $=\frac{\text { Total kondisi relai mesin menyala }}{\text { Total pengujian }} \times 100 \%$

$$
=\frac{10}{10} \times 100 \%=100 \%
$$


Jurnal IImu Teknik Elektro Komputer dan Informatika (JITEKI)

Vol. 4, No. 1, Juni 2018

\section{Pengujian saat memasukan kata sandi salah}

Ketika kata sandi yang dimasukkan tidak sesuai, maka relay coil yang dihubungkan dengan sambungan coil tidak terhubung dan kondisi relay alarm menyala. Hasil pengujian saat memasukan kata sandi salah dapat ditunjukkan pada Tabel 2.

Tabel 2. Hasil pengujian saat memasukan kata sandi salah.

\begin{tabular}{cccc}
\hline No & Percobaan & Kondisi Relay Coil & Kondisi Relay Alarm \\
\hline 1 & Percobaan 1 & Mati & Menyala \\
2 & Percobaan 2 & Mati & Menyala \\
3 & Percobaan 3 & Mati & Menyala \\
4 & Percobaan 4 & Mati & Menyala \\
5 & Percobaan 5 & Mati & Menyala \\
6 & Percobaan 6 & Mati & Menyala \\
7 & Percobaan 7 & Mati & Menyala \\
8 & Percobaan 8 & Mati & Menyala \\
9 & Percobaan 9 & Mati & Menyala \\
10 & Percobaan 10 & Mati & Menyala \\
\hline
\end{tabular}

Dari hasil pengujian pada Tabel 2 akurasi hasil optimum kondisi relay coil dan mesin dapat dihitung dengan persamaan sebagai berikut:

$$
\text { Akurasi kondisi relay coil }=\frac{\text { Total kondisi relaycoil menyala }}{\text { Total pengujian }} \times 100 \%
$$

$$
=\frac{10}{10} \times 100 \%=100 \%
$$

Akurasi keberhasilan kondisi mesin $=\frac{\text { Total kondisi relai mesin menyala }}{\text { Total pengujian }} \times 100 \%$

$$
=\frac{10}{10} \times 100 \%=100 \%
$$

Pengujian terhadap jarak jangkau infrared remote telah dilakukan pada jarak 1 meter, 3 meter, dan 7 meter dengan hasil yang dibuktikan bahwa remote dapat berfungsi secara konsisten yaitu relay alarm dapat dimatikan dengan infrared remote arduino.

3. Pengujian jarak jangkau infrared remote pada jarak 1 meter

Hasil pengujian saat mematikan alarm dengan menggunakan infrared remote dengan jarak 1 meter ditunjukkan pada Tabel 3.

Tabel 3. Hasil pengujian infrared remote dengan jarak 1 meter.

\begin{tabular}{ccc}
\hline No & Percobaan & Kondisi Relay Alarm \\
\hline 1 & Percobaan 1 & Mati \\
2 & Percobaan 2 & Mati \\
3 & Percobaan 3 & Mati \\
4 & Percobaan 4 & Mati \\
5 & Percobaan 5 & Mati \\
6 & Percobaan 6 & Mati \\
7 & Percobaan 7 & Mati \\
8 & Percobaan 8 & Mati \\
\hline
\end{tabular}


Jurnal IImu Teknik Elektro Komputer dan Informatika (JITEKI)

Vol. 4, No. 1, Juni 2018

\begin{tabular}{ccc}
\hline 9 & Percobaan 9 & Mati \\
10 & Percobaan 10 & Mati \\
\hline
\end{tabular}

Dari hasil pengujian pada Tabel 3 akurasi hasil optimum jarak jangkau infrared remote 1 meter dapat dihitung dengan persamaan sebagai berikut:

$$
\begin{aligned}
\text { Akurasi jarak remote } 1 \text { meter }= & \frac{\text { Total kondisi relai alarm mati }}{\text { Total pengujian }} \times 100 \% \\
& =\frac{10}{10} \times 100 \%=100 \%
\end{aligned}
$$

Berdasarkan Tabel 3 maka dapat ditunjukkan dari percobaan 1 sampai 10 jarak jangkau infrared remote 1 meter bekerja secara konsisten yaitu relay alarm dapat dimatikan dengan infrared remote arduino.

4. Pengujian jarak jangkau infrared remote pada jarak 3 meter

Hasil pengujian saat mematikan alarm dengan menggunakan infrared remote dengan jarak 3 meter disajikan pada Tabel 4.

Tabel 4. Hasil pengujian infrared remote dengan jarak 3 meter.

\begin{tabular}{ccc}
\hline No & Percobaan & Kondisi Relay Alarm \\
\hline 1 & Percobaan 1 & Mati \\
2 & Percobaan 2 & Mati \\
3 & Percobaan 3 & Mati \\
4 & Percobaan 4 & Mati \\
5 & Percobaan 5 & Menyala \\
6 & Percobaan 6 & Mati \\
7 & Percobaan 7 & Menyala \\
8 & Percobaan 8 & Mati \\
9 & Percobaan 9 & Mati \\
10 & Percobaan 10 & Mati \\
\hline
\end{tabular}

Hasil percobaan pada Tabel 4 akurasi hasil optimum jarak infrared remote 3 meter dapat dihitung dengan persamaan sebagai berikut:

Akurasi jarak remote 3 meter $=\frac{\text { Total kondisi relai alarm mati }}{\text { Total pengujian }} \times 100 \%$

$$
=\frac{8}{10} \times 100 \%=80 \%
$$

Dari hasil percobaan pada Tabel 4 maka dapat ditunjukkan dari percobaan 1 sampai 10 , jarak infrared remote yaitu 3 meter terjadi kendala sebanyak 2 kali sehingga relay alarm 2 kali tidak dapat dimatikan dengan infrared remote arduino. Persentase keberhasilan pengujian dengan jarak jangkau infrared remote 3 meter yaitu $80 \%$.

5. Pengujian jarak jangkau infrared remote pada jarak 7 meter

Hasil pengujian saat mematikan alarm dengan menggunakan infrared remote dengan jarak 7 meter ditunjukkan pada Tabel 5 . 
Jurnal IImu Teknik Elektro Komputer dan Informatika (JITEKI)

Vol. 4, No. 1, Juni 2018

Tabel 5. Hasil pengujian infrared remote dengan jarak 7 meter.

\begin{tabular}{ccc}
\hline No & Percobaan & Kondisi Relay Alarm \\
\hline 1 & Percobaan 1 & Mati \\
2 & Percobaan 2 & Mati \\
3 & Percobaan 3 & Mati \\
4 & Percobaan 4 & Mati \\
5 & Percobaan 5 & Menyala \\
6 & Percobaan 6 & Mati \\
7 & Percobaan 7 & Menyala \\
8 & Percobaan 8 & Menyala \\
9 & Percobaan 9 & Menyala \\
10 & Percobaan 10 & Mati \\
\hline
\end{tabular}

Hasil percobaan pada Tabel 5 akurasi hasil optimum jarak infrared remote 7 meter dapat dihitung dengan persamaan sebagai berikut :

Akurasi jarak remote 7 meter $=\frac{\text { Total kondisi relai alarm mati }}{\text { Total pengujian }} \times 100 \%$

$$
=\frac{6}{10} \times 100 \%=60 \%
$$

Dari hasil percobaan pada Tabel 5 maka dapat ditunjukkan dari percobaan 1 sampai 10 , jarak infrared remote 7 meter terjadi kendala sebanyak 4 kali sehingga relay alarm 4 kali tidak dapat dimatikan dengan infrared remote arduino. Persentase keberhasilan pengujian dengan jarak jangkau infrared remote 7 meter yaitu $60 \%$.

\section{Kesimpulan}

Berdasarkan proses penelitian menunjukkan bahwa fungsi sistem pengaman sepeda motor yang dibangun dapat bekerja secara optimum yang dibuktikan dengan akurasi hasil pengujian mencapai rerata 100\% ketika kondisi pengunaan kata sandi. Selain itu ketika pengujian proses aktivasi alarm menggunakan remote dengan kondisi berbeda menunjukkan rerata akurasi sebesar $100 \%$ jarak 1 meter, $80 \%$ jarak 3 meter, dan $60 \%$ jarak 7 meter.

\section{Referensi}

[1] Akhmad Fauzi, Mushlihudin, Rancangan Sistem Palang Pintu Otomatis Pada Jalur Bus Rapid Transit Berbasis Arduino. Jurnal IImiah Teknik Elektro Komputer dan Informatika (JITEKI). 2017; 03(4): 11.

[2] Ibrahim, Wahyu. Prototipe Sistem Pengaman Sepeda Motor Menggunakan SMS Gateway Berbasis Mikrokontroler ATMega32. Yogyakarta, Universitas Ahmad Dahlan.2016.

[3] Dwi Ely Kurniawan, Muhamad Naharus Surur, Perancangan Sistem Pengamanan Sepeda Motor Menggunakan Mikrokontroler Raspberry Pi dan Smartphone Android. Jurnal Komputer Terapan. 2016; 02(02): 94.

[4] Supiati, H. Muh Yudi, Sitti Chadijah. Pengaruh Konsetrasi Aktivator Asam Klorida (HCL) Terhadap Kapasitas Adsorpsi Arang Aktif Kulit Durian Pada Zat Warna Methanol Yellow. Jurnal Teknik Kimia. 2013; 02(02): 54

[5] Santoso, Ervin Setyobudi. Prototipe Sistem Keamanan Pintu Ruangan Menggunakan Barcode Kata sandi Dan Pin Kata sandi .Yogyakarta, Universitas Ahmad Dahlan.2007.

[6] Kadir, Abdul. From Zero to a Pro Arduino. Yogyakarta: Andi Publisher. 2014. 
Jurnal IImu Teknik Elektro Komputer dan Informatika (JITEKI)

Vol. 4, No. 1, Juni 2018

[7] Mochamad Teguh Kurniawan, Achmad Rizal. Rancang Bangun Sistem Pengaman Sepeda Motor Anti Maling. Prosiding SENTIA. Malang. 2009: E-103

[8] Solikin, Achmad. Rancang Bangun Keamanan Sepeda Motor Via Sms Dengan Arduino. Yogyakarta: STIMIK AMIKOM. 2013.

[9] Karseno, D.Sistem Pengamanan Rumah Dengan Security Kata sandi Menggunakan Remote Berbasis Mikrokontroller Arduino. Yogyakarta: Sekolah Tinggi Manajemen Informatika Dan Komputer Amikom. 2011.

[10] Suwarto, Toto. Mencari dan memperbaiki Kerusakan Sepeda Motor 4-tak. Jakarta Selatan: Kawan Pustaka. 2008.

[11] Kadir, Abdul. From Zero to a Pro Arduino. Yogyakarta: Andi Publisher. 2014.

[12] Aan Marianto, Muchlas, Rancang Bangun Robot Forklift Dengan Kendali Smartphone Android Berbasis Arduino Mega 2560. Jurnal IImiah Teknik Elektro Komputer dan Informatika (JITEKI). 2017; 03(2): 20. 